\title{
Analysis of Achyranthes aspera leaf extract and environmental safety evaluation to non target Nile tilapia fish fingerlings, Oreochromis niloticus.
}

Belayhun Mandefro ( $\sim$ belayhunmandefro@gmail.com )

Dilla University https://orcid.org/0000-0003-2113-6671

Mereta Seid Tiku

Jimma University College of Public Health and Medical Sciences

Dawit Fremichael

Addis Ababa University Faculty of Science: Addis Ababa University College of Natural Sciences

Workineh M. Fereja

Mekelle University College of Natural and Computational Sciences

Argaw Ambelu

Jimma University College of Public Health and Medical Sciences

Research

Keywords: Achyranthes aspera, molluscicidal, NOAEC, Oreochromis niloticus, piscicidal, phytochemical

Posted Date: April 9th, 2021

DOI: https://doi.org/10.21203/rs.3.rs-397933/v1

License: (9) This work is licensed under a Creative Commons Attribution 4.0 International License. Read Full License 


\section{Analysis of Achyranthes aspera leaf extract and environmental safety evaluation to}

2 non target Nile tilapia fish fingerlings, Oreochromis niloticus.

3 Belayhun Mandefro ${ }^{1,2, *}$, Seid Tiku Mereta ${ }^{1}$, Dawit Fremichael ${ }^{3,5}$, Workineh M. Fereja ${ }^{3,4}$,

$4 \quad$ Argaw Ambelu ${ }^{1}$

$5{ }^{1}$ Department of Environmental Health Science and Technology, Jimma University,

6 Jimma, Ethiopia.

$7 \quad{ }^{2}$ Department of Biology, Dilla University, Dilla, Ethiopia.

$8 \quad{ }^{3}$ Department of Chemistry, Dilla University, Dilla, Ethiopia.

$9{ }^{4}$ Energy and Environment Research Center, Dilla University, Dilla, Ethiopia.

$10{ }^{5}$ Department of Environmental Science, Addis Ababa University, Addis Ababa, Ethiopia.

11 Author E-mail addresses

12 Belayhun Mandefro; belayhunmandefro@gmail.com

13 Argaw Ambelu; aambelu@yahoo.com

14 Seid Tiku Mereta; seidtiku@yahoo.com/seid.tiku@ju.edu.et

15 Workineh Mengesha Fereja; workinehmengesha@gmail.com

16 Dawit Fremichael: dawitfiremichael@gmail.com

\section{*Corresponding author address:}

18 Belayhun Mandefro: Tel: +251911185328, E-mail: belayhunmandefro@gmail.com 


\section{Abstract}

26 Background: Although plant molluscicides are biodegradable and less toxic to higher

27 animals, unregulated applications could affect other non target aquatic species. Eco

28 toxicological studies are required to evaluate whether they are safe to those economically

29 and ecologically important fish species. According to previous studies, Achyranthes

30 aspera is a molluscicidal plant with $\mathrm{LC}_{90}$ of $96.5 \mathrm{mg} / \mathrm{L}$ and the current study is to

31 investigate its toxic effect to Nile tilapia fish fingerlings, Oreochromis niloticus.

32 Methods: Seven fish fingerlings were exposed to serial dilutions of $A$. aspera leaf 33 aqueous extract for 96 hours in duplicate setup. Phytoconstituents were identified by GC-

34 MS and lethal concentrations were determined by probit model. The NOAEC was 35 determined by hypothesis testing on the survival data.

36 Results: The respective piscicidal $\mathrm{LC}_{1}, \mathrm{LC}_{10}$ and $\mathrm{LC}_{50}$ values were 897.4, 1063.9 and

$371310.74 \mathrm{mg} / \mathrm{L}$. The NOAEC was $1100 \mathrm{mg} / \mathrm{L}(\mathrm{p}>0.05)$. GC-MS analysis revealed 12

38 phytoconstituents including a monoterpene.

39 Conclusion: The result shows that $A$. aspera is non toxic and hence is safe to Nile tilapia

40 fish especially at its molluscicidal dose limit $(96.5 \mathrm{mg} / \mathrm{L} \mathrm{LC} 90)$ corroborating to the plant's

41 target specific molluscicidal potential.

42 Keywords: Achyranthes aspera, molluscicidal, NOAEC, Oreochromis niloticus, 43 piscicidal, phytochemical 


\section{Background}

49 Awareness on the detrimental impact of synthetic pesticides on the environment coupled with increasing prices is forcing researchers and communities to look for alternative botanical products [1]. Ease of access at low cost and environmental friendliness are the major attributes of many medicinal plants. Similar refreshment is being observed in the search for molluscicidal plants against vector snails transmitting schistosomiasis and other trematode parasites[2, 3].

Even though, plant molluscicides are generally considered as ecofriendly, rapidly biodegradable and less toxic to higher animals, their indiscriminate use could cause risk to many nontarget organisms. Toxic effects of these products at least to those important species should be investigated beforehand. Lack of such ecotoxicological information is a hindrance to their practical applicability $[4,5]$ Acute fish toxicity assessments were performed on few molluscicidal plants. For instance, the toxicity effect of Phytolacca dodecandra to aquatic invertebrates Daphnia Magna and fish (Pimephales Promelas) was discussed in a study by Lambert et al., [6]. Similarly, toxicity of Jatropha curcas on certain aquatic crustaceans and annelids was evaluated by Rug and Ruppel [7]. Acute toxicity of Moringa oleifera to Nile tilapia Oreochromis niloticus fingerlings is also studied $[4,8]$.

Beside toxicity studies, knowledge of the chemical constituents of such plants is desirable to develop a more comprehensive information regarding its toxicological potential, safety and efficacy [9]. In addition, identification of bioactive compounds is useful for further understanding of its molluscicidal properties and for the synthesis of effective chemical substances [10]. 
Achyranthes aspera, (Amaranthaceae), also known as "devil's horsewhip" is stiff erect perennial herb growing as a weed in many parts of Asia, Africa, America, Europe and Australia [11-13]. It is a well-known medicinal plant in Ethiopia, India and other countries as antifungal, antibacterial, antioxidant, antifertility and in the treatment of renal dropsy, skin rash, chronic malaria, impotence, asthma, diabetes etc.[14-16]. Very recently, The molluscicidal property of $A$. aspera is discovered by after investigation on the aqueous and ethanolic extracts as well as in bait formulation $[17,18]$.

Phytochemical analyses carried out on A. aspera have revealed several compounds including flavonoids, alkaloids, saponins and cardiac glycosides.[16, 19-21]. Saponins and alkaloids are molluscicidal; also, piscicidal. Therefore, the plant's molluscicidal application requires further phytochemical analysis and ecotoxicological investigations.

82 This study is aimed to identify the major phytoconstituents present in $A$. aspera leaves and investigate its acute toxicity to fingerlings of Nile tilapia, O. niloticus.

Nile tilapia is an African freshwater cichlid fish naturally occurring in rivers, dams and lakes as an important ecological entity. It is an important food fish all over the world and

86 is most exploited species constituting $60-80 \%$ total fish capture [22-25]. Moreover, it is one of the predominantly stocked fish in aquacultures, artificial lakes, reservoirs and small water bodies.

\section{$89 \quad$ Materials and methods}

90 A standard non-renewed static test was adopted for this test to evaluate the fish acute

91 toxicity of A. aspera leaf aqueous extract in 96 hours exposure time.

\section{Plant Material Collection and Processing}

93 Fresh leaves of A. aspera plant are collected in October 2017 from a natural habitat 
94 located at 943'45.59" N, 39³7'2.71" E in Debre Berhan Zuria-Keyit District in Amhara

95 region, Ethiopia. The leaves were dried in the shade to a final weight and ground to a 200

$96 \mu \mathrm{m}$ mesh sized powder using an electric blender. For each serial dilution, crude aqueous

97 extraction was made at the time of experimentation, by soaking the required amount in

$98400 \mathrm{ml}$ aged water in a conical flask and shaking overnight in an orbital shaker at 160

99 rpm. Finally, it was filtered using a clean cotton filtering cloth where the filtrate was then

100 transferred in to a volumetric flask, tightly capped and stored in the refrigerator at $4^{\circ} \mathrm{C}$.

\section{Test Animal Collection and Maintenance}

102 Fingerlings of $O$. niloticus were collected from an artificial fishpond in Dilla University 103 main compass, southern Ethiopia. The owner of the pond, Department of Biology, has 104 permitted us to take 110 fingerlings. A skilled person assigned to manage the pond, caught

105 the fish with care by a small handmade fishing net. Both male and female fingerlings of 106 length 5.9-6.6 $\mathrm{cm}(6.27 \pm 0.2 \mathrm{~cm})$ and mass 3.4-4.3 $\mathrm{g}(3.89 \pm 0.25 \mathrm{~g})$ were selected for this

107 test and the remaining were immediately returned in to the pond. Caught fish were 108 promptly put into clean plastic buckets containing the pond water and immediately 109 brought to the laboratory for acclimatization. They were maintained in two $80 \mathrm{~cm} \times 60$

$110 \mathrm{~cm} \times 60 \mathrm{~cm}$ aquaria for one week in aged tap water under continuous aeration and 12-

111 hour light, 12-hour dark photoperiod. They were fed with flakes of tasty soya (Pramukh

112 Agroindustry PLC, Ethiopia) as recommended [26]. Feeding was stopped 24 hours prior 113 to the start of experiment [27, 28].

\section{Range Finding Test}

115 The range finding test was set according to the protocols defined by OECD [29] and EPA

116 [30]. Five serial dilutions of $100,400,800,1200$ and $1600 \mathrm{mg} / \mathrm{L}$ aqueous extract were

117 prepared in $10 \mathrm{~L}$ aged water. Three randomly selected healthy fish were exposed to each 
118 test solution for 24 hours. The purpose of the range finding test is to identify the useful

119 concentration range that would probably produce mortality rates between 0 and $100 \%$

120 and guess the range of concentrations for the definitive test.

\section{Definitive Test}

122 Six serial dilutions: 600, 800, 1000, 1100, 1200 and $1400 \mathrm{mg} / \mathrm{L}$ were prepared in $30 \mathrm{~L}$

123 aged tap water. According to the protocols [29, 31], seven healthy fishes were randomly

124 released in to each test solution for 96-hour exposure time. Only aged tap water was used

125 for negative control. The whole test was prepared in duplicates. Each solution and the

126 controls were intermittently aerated for about 40 minutes in every 2-3 hours.

\section{Physicochemical Characteristics of Test Water}

128 Dissolved oxygen, temperature and $\mathrm{pH}$ were measured in every 24 hours using a

129 multiparameter probe. Before every measurement, the probe was calibrated according to

130 its operating manual. Total hardness was measured only once at the start by EDTA

131 titrimetric method. Eriochrome Black T (EBT) was used as indicator. First, $100 \mathrm{ml}$ sample

132 water was buffered by $2 \mathrm{ml}$ ammonium hydroxide to $\mathrm{pH} 10$. When few drops of EBT was

133 added to this sample water, a wine-red color appeared. Upon titration with EDTA, the

134 color gradually changes to blue. At this instance of color change, the titration was

135 Immediately stopped and the final volume of the ample water was noted

$$
\text { Hardness }(\text { in } \mathrm{mg} / \mathrm{L} \text { as CaCO3 })=(V \times N \times 50 \times 1000) /(S V)
$$

137 Where: $\mathrm{V}=$ volume of titrant $(\mathrm{ml}) ; \mathrm{N}=$ normality of EDTA; $50=$ equivalent weight of

$138 \quad \mathrm{CaCO}_{3} ; \mathrm{SV}=$ sample volume $(\mathrm{ml})$ 
139 The course of the experiment was monitored through constant and careful bench side

140 observation and cumulative mortalities were recorded at the end of 12, 24, 48, 72 and 96

141 hours according to OECD [29]. Dead fish were identified by absence of tail and gill

142 movements and loss of sensation to gentle prodding with a glass rod [32]. Dead fish were

143 immediately picked out from the solutions to minimize contamination.

\section{Phytochemical Analysis of A. aspera by GC-MS}

145 The chemical profile of $A$. aspera leaf crude ethanolic extract was documented from GC-

146 MS analysis employing Agilent- Technologies (Little Falls, CA, USA) 6890N Network

147 Gas Chromatographic system, equipped with an inert XL Mass detector (Agilent-

148 Technologies 5975), auto injector (Agilent-Technologies 7683B series) and HP-5MS 5\%

149 Phenyl Methyl Silox capillary column (27 m x $250 \mu \mathrm{m}$ with film thickness x $0.24 \mu \mathrm{m})$.

150 The cured extract was clean up by silica gel and dissolved in HPLC grade n-hexane with

151 a ratio of 1:99. This mix was ready for GC-MS analysis. 1.0 $\mu \mathrm{L}$ sample was injected in

152 the split less mode. Helium was used as a carrier gas with a flow rate of $1 \mathrm{ml} / \mathrm{min}$. The

153 temperature of column oven was programmed started from $40{ }^{\circ} \mathrm{C}$ for 0 min to $100{ }^{0} \mathrm{C}$ at

$1544{ }^{\circ} \mathrm{C} / \mathrm{min}$ and from 100 to $310{ }^{\circ} \mathrm{C}$ at $10{ }^{\circ} \mathrm{C} / \mathrm{min}$ while initial and final holdup time was

1551 and $16 \mathrm{~min}$, respectively. The temperature of the injector and MS transfer line were set

156 at 250 and $280{ }^{\circ} \mathrm{C}$, respectively. An electron ionization system (with ionization energy of

$15770 \mathrm{eV}$ ) was used for GC/MS detection while the scanning mass was ranged from 33-500

$158 \mathrm{~m} / \mathrm{z}$.

\section{Data Analysis}

160 The phytoconstituents were identified by comparing the spectra of each unknown

161 component with the spectrum of known compounds archived in a database repository. 
162 Effective doses $\left(\mathrm{LC}_{1}, \mathrm{LC}_{10}\right.$ and $\left.\mathrm{LC}_{50}\right)$ were determined from the mortality data by probit

163 regression method in IBM SPSS software, version 23. Mean and standard deviations of

164 fish weight and lengths as well as the water physicochemical parameters were computed

165 in Microsoft excel spreadsheet of Office 2016.

166 The NOAEC (No-Observed-Adverse-Effect-Concentration) is by definition, the highest

167 concentration at which survival of the test organism is not significantly different from the

168 control $[30,33]$. In other words, it is the highest concentration from the serial dilutions in

169 which the number of fishes died is not significantly different from that in the control.

170 Therefore, the NOAEC was determined by hypothesis testing using Dunnett $\mathrm{t}$ test at $95 \%$

171 confidence interval [30].

172 First: the mortality rates are recorded as response proportion data for each concentration

173 and control group.

$174(R P)=$ Number of survivors / Total exposed; where RP is Response Proportion

175 Second: The resulting RPs are transformed to arc sine values in radian as follows

176 (1) For RPs greater than zero or less than one

$$
\text { Angle }(\text { in radians })=\operatorname{arcsine} \sqrt{(R P)}
$$

(2) Modification of the arc sine when $\mathrm{RP}=0$.

$$
\text { Angle }(\text { in radians })=\operatorname{arc~sine} \sqrt{1 / 4 n}
$$

180 where $\mathrm{n}=$ number of animals per treatment replica.

181 (3) Modification of the arc sine when $\mathrm{RP}=1.0$. 
183 Third: Dunnett test is performed on the arc sine transformation of the corresponding 184 mortality data at $95 \%$ confidence interval to determine which maximum concentration 185 exhibited statistically insignificant difference from the control.

\section{Results}

\section{Bench side observation}

188 The fingerlings remained very active in swimming and feeding in the course of

189 acclimatization. No fish has died in the aquaria and no one has exhibited any abnormal 190 operculum beating as signs of stress or suffocation. In few moments following loading of

191 fish to the aquaria, few fingerlings jumped out but were promptly picked up and returned.

192 Afterwards, they became calm and relaxed within 2-3 hours. Unlike the control groups,

193 fish exposed to the test solutions are constantly coming to the air water interface and

194 continuously gulp. They usually come to the surface and gulp in groups or rest at the 195 bottom unlike the control groups which were freely moving and chasing each other.

\section{Physicochemical Properties of the Test Water}

197 Lower level of dissolved oxygen was detected in all test solutions other than the control

198 in every measurement. On the other hand, $\mathrm{pH}$ measurements of the first day were higher

199 than those in the other days. Standard deviation of the temperature recorded was less than 200 the 1.5 maximum limit set by OECD for a valid test [29]. In addition, all dissolved oxygen

201 measurements were above $60 \%$.

\section{Range Finding Test Results}

203 In the range finding test, the 100, 400 and $800 \mathrm{mg} / \mathrm{L}$ dilutions did not kill any fish. Rather, 204 fish death was observed at 1200 and $1600 \mathrm{mg} / \mathrm{L}$ solutions where, the former killed two 
and the later killed all the three. Based on the result, five equidistant concentrations

206 between 800 and $1600 \mathrm{mg} / \mathrm{L}$ were suggested for the definitive test. The researchers

207 discussed on it and decided to include a $600 \mathrm{mg} / \mathrm{L}$ dilution and avoided the upper most

$2081600 \mathrm{mg} / \mathrm{L}$ level. The underlying rationale was that, as the exposure time extends from

20924 to 96 hours, fish would become weaker due to prolonged starvation and hence, their

210 resistance declines. On the other hand, prolonged exposure could aggravate toxic effects.

211 Thus, serial dilutions of $600,800,1000,1100,1200$ and $1400 \mathrm{mg} / \mathrm{L}$ were set for the

212 definitive test.

\section{Definitive Test Results}

214 The definitive test was started with the expectation that, the extended exposure time (96

215 hours) will increase toxicity of the extract. As a result, fish mortality will be higher in the

216 third and fourth day than in the first and second. However, contrary to this, the mortality

217 data shows that most fish deaths were recorded in the first 48 hours (Table 1).

218 Table 1. Cumulative mortalities of 0 . niloticus fish fingerlings in different extract

219 concentrations during 24,48, 72 and 96 hours of exposure

\begin{tabular}{llllll}
\hline \multirow{2}{*}{$\begin{array}{l}\text { Test } \\
(\mathrm{mg} / \mathrm{L})\end{array}$} & conc. & $\begin{array}{l}\text { Number } \\
\text { exposed }\end{array}$ & of & fish & \multicolumn{4}{l}{ Fish cumulative mortalities at different time intervals } \\
\cline { 4 - 6 } & 14 & 24 hours & 48 hours & 72 hours & 96 hours \\
\hline $0($ Control $)$ & 14 & 0 & 0 & 0 & 0 \\
600 & 14 & 0 & 0 & 0 & 0 \\
800 & 14 & 0 & 0 & 0 & 0 \\
1000 & 14 & 0 & 0 & 0 & 1 \\
1100 & 14 & 0 & 1 & 1 & 1 \\
1200 & 14 & 3 & 5 & 5 & 5 \\
1400 & 14 & 3 & 6 & 7 & 9 \\
\hline
\end{tabular}

221 When the test solutions were discarded at the end, a large amount of fish faeces is found 222 decanted at the bottom of the containers but only in the experimental groups. No fish has 
223 died in the control as well as in the lower 600 and $800 \mathrm{mg} / \mathrm{L}$ dilutions nor did the highest

$2241400 \mathrm{mg} / \mathrm{L}$ concentration kill all fishes. Dying fish gradually loose activity and become 225 sluggish, unable to escape when touched. They continuously swirl about unguided and 226 finally sank down.

227 Table 2. Lethal concentrations and confidence intervals resulted from probit analysis

\begin{tabular}{llll}
\hline $\begin{array}{l}\text { Lethal } \\
\text { concentrations }\end{array}$ & $\begin{array}{l}\text { Concentration in } \\
(\mathrm{mg} / \mathrm{L})\end{array}$ & $\begin{array}{l}\text { Confidence interval } \\
(\text { at 95\%) }\end{array}$ & $\chi^{2}$ \\
\hline LC1 & 897.43 & $642.48-1006.01$ & 1.02 \\
LC10 & 1063.87 & $903.01-1140.89$ & \\
LC50 & 1310.74 & $1229.53-1484.42$ &
\end{tabular}

229 Concentrations that can cause $1 \%$ and $10 \%$ mortalities as well as median lethal

230 concentration with corresponding upper and lower limits, in 96-hour exposure were

231 determined from the mortality data by probit analysis (Table 2). Within the 95\%

232 confidence interval, the calculated $\chi^{2}$ is less than the corresponding tabular value asserting

233 the model's goodness-of-fit.

234 The response proportions (RP), or survival proportions and the corresponding arc sine 235 square root transformed values in each test solution of the two replicas are summarized 236 in table 3. The results of Dunnett test on the arc sine square root transformed RP data 237 showed that the highest concentration in which survival of the fingerlings is not 238 significantly different from the control is the $1100 \mathrm{mg} / \mathrm{L}$ solution $(\mathrm{p}>0.05)$. This level is 239 therefore, the NOAEC.

240 Table 3. Arc sine transformation of survival proportion data

$$
\text { Replicate } \quad \mathrm{RP} \text { in each test concentration and the control }
$$




\begin{tabular}{lcccccccc}
\cline { 3 - 8 } & & & 600 & 800 & 1000 & 1100 & 1200 & 1400 \\
$\mathrm{mg} / \mathrm{L}$ & $\mathrm{mg} / \mathrm{L}$ & $\begin{array}{c}\mathrm{mg} / \mathrm{L} \\
\mathrm{mg} / \mathrm{L}\end{array}$ \\
\hline Raw data & $\mathrm{A}$ & 1.0 & 1.0 & 1.0 & 1.0 & 1.0 & 0.7 & 0.4 \\
& $\mathrm{~B}$ & 1.0 & 1.0 & 1.0 & 0.9 & 0.9 & 0.6 & 0.3 \\
\hline Arc sine & $\mathrm{A}$ & 1.3807 & 1.3807 & 1.3807 & 1.3807 & 1.3807 & 1.0069 & 0.7137 \\
value & $\mathrm{B}$ & 1.3807 & 1.3807 & 1.3807 & 1.1832 & 1.1832 & 0.8531 & 0.5640 \\
& Mean & 1.3807 & 1.3807 & 1.3807 & 1.2820 & 1.2820 & 0.9300 & 0.6389 \\
& Var & 0 & 0 & 0 & 0.0195 & 0.0195 & 0.0118 & 0.0112 \\
\hline
\end{tabular}

Phytochemical Analysis of A. aspera Leaf Ethanolic Extract

243 The leaf powder was extracted by $85 \%$ ethanol using microwave assisted extraction

244 technique. The resulting extract was analysed by GC-MS and revealed 12 major 245 phytoconstituents (Fig. 1.).

\section{Discussion}

247 Achyranthes aspera is a well-known medicinal plant traditionally used for ailments of 248 various diseases in many parts of the world [14]. In addition, the molluscicidal potential 249 of this plant is recently discovered [17] But assessment on its negative toxic impact on 250 non target species is mandatory before applied in the aquatic environment for snail 251 control.

252 Here, the toxic effect of $A$. aspera leaf aqueous extract on an important fish species, $O$.

253 niloticus fingerlings, was studied to evaluate the possible adverse impact on survival of 254 such non-target and important species in case of its application against aquatic vector 255 snails. As a result, the NOAEC was determined to be $1100 \mathrm{mg} / \mathrm{L}(\mathrm{p}>0.05)$ and the $\mathrm{LC}_{50}$ 256 was $1310.74 \mathrm{mg} / \mathrm{L}$. In addition, the respective $\mathrm{LC}_{1}$ and $\mathrm{LC}_{10}$ values were $897.43 \mathrm{mg} / \mathrm{L}$ 257 and $1063.87 \mathrm{mg} / \mathrm{L}$.

258 Regarding the toxicity effect of different molluscicidal plants on fishes, Sapindus 
mukorossi exhibited an $\mathrm{LC}_{50}$ of 10 ppm while its molluscicidal $\mathrm{LC}_{50}$ is $119.57 \mathrm{ppm}$ [34].

260 Jatropha gossypifolia had piscicidal $\mathrm{LC}_{50}$ of $10.490 \mathrm{mg} / \mathrm{L}$ [35] while its molluscicidal

261 LC50 is over 100 ppm [36].[36] The piscicidal LC 50 of Endod (Phytolacca dodecandra)

262 is $4.4 \mathrm{mg} / \mathrm{L}$ and its molluscicidal $\mathrm{LC}_{50}$ is $10 \mathrm{ppm}[37,6]$. Similarly, Carica papaya

263 exhibited piscicidal LC50 of 700 ppm against $O$. mossambicus fish while its molluscicidal

$264 \mathrm{LC}_{50}$ is from 619.1 to $2716.3 \mathrm{ppm}$ [38]. These data indicate the molluscicidal median

265 lethal dose $\left(\mathrm{LC}_{50}\right)$ of each plant exceeds its respective piscicidal $\mathrm{LC}_{50}$. And hence, they

266 are more toxic to those nontarget fishes than to the target snails. Such problem in

267 selectivity and target specificity limits application of these natural products for snail

268 control in habitats where fishes and snails co-exist.

269 On the contrary, the current study showed that the piscicidal $\mathrm{LC}_{50}$ of $A$. aspera leaf 270 aqueous extract to Nile tilapia fingerlings is $1310.74 \mathrm{mg} / \mathrm{L}$. Similarly, the NOAEC level 271 is $1100 \mathrm{mg} / \mathrm{L}$. These concentrations are much higher than its molluscicidal LC 50 which is 27272.4 ppm, according to Mandefro et al.,[18]. The considerable gap between the molluscicidal and piscicidal lethal doses of $A$. aspera indicates that the plant has very low

274 or negligible toxic effect on this economically and ecologically valuable fish, O. niloticus,

275 especially at its molluscicidal dose limits.

276 Several phytochemical analyses of the plant have been carried out by different 277 researchers, and they were able to identify different classes of saponins $[11,39,40]$. But 278 in the current GC-MS analysis, saponins are not detected (Fig.1). However, some 279 compounds identified are molluscicidal by nature. For example, cis-p-mentha-1(7),8280 dien-2-ol is an oxygenated monoterpene, a terpenoid saponin moiety [41]. The 281 molluscicidal effect of terpenoids is indicated in many literature [4, 42]. In addition, the 282 larvicidal property of eicosanoic acids, and phthalates is indicated in many literatures. In 
283 general, bioactivity of crude extracts usually arises from synergistic effect of several 284 constituents.

285 In all measurement instances of the test water physico chemical parameters, lower 286 dissolved oxygen level was recorded in test solutions than in the control. This 287 phenomenon agrees with the studies of Ayuba et al.,[32] and Ojutiku et al., [43]. 288 Biodegradation or decomposition of the phytochemicals leads to higher biological and 289 chemical oxygen demand (BOD, COD) and causes depletion of oxygen in the solutions $290[30,43]$.

291 Fingerlings in the test solution were seen motionless resting at the bottom or incessantly 292 gulping at the water air interface. These behavioural changes also happened in many 293 similar studies $[27,35,44]$. The reactions could be due to dissolved oxygen depletion by 294 the chemicals leading to oxidative stress [43]. It can also be a manifestation of neuro 295 toxicity and poisoning of the gills by the toxicants $[35,44]$.

\section{Conclusion}

297 As a general principle, molluscicides are directly applied in to the snail infested water

298 body where many other non-target and valuable species co-exist. As a result, they are 299 always subjected to deleterious toxicity by such chemicals applied in to their common

300 habitats. To mitigate such ecological damage, the molluscicide should be selective in 301 action or the dose limit applied for snail control is proved to be safe to such non-target 302 species.

303 Molluscicidal plants application in the field can be promoted when molluscicidal efficacy 304 studies are supported by eco toxicological safety data. This particular study showed that A. aspera aqueous extract is almost nontoxic to $O$. niloticus fingerlings and is safe to this 
306 fish when applied under its molluscicidal dose limit which is below 100ppm. Therefore,

307 it is possible to conclude that application of the plant product for snail control at 308 molluscicidal effective concentrations of below $100 \mathrm{ppm}$ does not acutely toxify this fish

309 species. However, further studies involving additional non-target groups such as aquatic

310 invertebrates and mammals should be conducted to generate a more complete

311 ecotoxicological information.

\section{Acknowledgements}

313 The authors are thankful to Jimma University and Dilla University for their financial

314 supports. Special thanks to the Department of Biology, Dilla University for its kind

315 supply of test fish and laboratory facilities. In addition, several individuals have

316 contributed a lot in many ways for the success of this study. Mr. Hailu Mandefro and

317 Ms. Alemtsahay Hagos have helped us in collection, transport and processing the plant

318 sample. Misses; Lubaba Mohammed, Touba Negash and Meron Lemma have supported

319 us with supply of several water containers and equipment. Mr. Nebiyu Mohammed, a

320 fishery expert, has consulted us in fish catching and acclimatization activities. The authors

321 are grateful to all of them.

322 Funding

323 Jimma University and Dilla University, Ethiopia, have done financial supports

324 for the study.

325 Availability of data and materials

326 All data generated or analyzed during this study are included in this

327 published article.

328 Authors' contributions

329 BM: Contributed in the conception of the study, carried out the experiment, 
and wrote the manuscript. STM: Modified the experimental design,

331 supervised the experiment process, and edited the manuscript. AA: Carried

332 out the statistical analysis, organized literatures and edited the final version

333 of the manuscript. YT: Did the phytochemical analysis section and edited the

334 revised manuscript. WM: Carried out water physicochemical measurements and edited

335 the manuscript. DF: Did the phytochemical analysis using GC-MS. All authors read and

336 approved the final manuscript.

337 Ethics approval

338 The internal review board (IRB) of college of Public Health, Jimma University,

339 has issued ethical clearance for this study.

\section{Consent for publication}

$341 \quad$ Not applicable

\section{Competing interests}

343 All authors of this revised manuscript declare that they have no competing

344 interest regarding this research

\section{References}

346 1. Medhi SM, Reza S, Mahnaz K, Reza AM, Abbas H, Fatemeh M, et al. Phytochemistry 347 and larvicidal activity of Eucalyptus camaldulensis against malaria vector, Anopheles 348 stephensi. Asian Paci J Trop Med. 2010;841-5; doi:10.1016/S1995-7645(10)60203-9.

349 2. Otarigho B, Morenikeji OA. Molluscicidal effects of aqueous and ethanolic extracts of 350 Lemongrass (Cymbopogon citratus) leaf against the different developmental stages of 351 Biomphalaria pfeifferi. NY Sci J. 2012;5:70-7.

352 3. Forstinus NO, Ikechukwu NE, Emenike MP, Osita O. Synthetic insecticides, 353 phytochemicals and mosquito resistance. Acad J Biotechnol. 2017;5:118-25.

354 4. Rocha-filho CAA, Albuquerque LP, Silva LRS, Silva PCB, Coelho LCBB, Navarro 

glabrata , Schistosoma mansoni and Artemia salina. Chemosphere. 2015;132:188-92; doi: 10.1016/j.chemosphere.2015.03.041.

5. Singh A, Singh D, Misra T, Agarwal R. Molluscicides of plant origin,biological agriculture \& horticulture. Int J Sustain Prod Syst. 2012;13:205-52; doi:10.1080/01448765.1996.9754782

6. Lambert J, Temmink J, Marquis J, Parkhurst R, Lugt C, Lemmich E, et al. Endod: Safety evaluation of a plant molluscicide. Regul Toxicol Pharmacol. 1991;14:189-201.

7. Rug M, Ruppel A. Toxic activities of the plant Jatropha curcas against intermediate snail hosts and larvae of schistosomes. Trop Med Intern Heal. 2000;5:423-430. oleifera seed powder to Nile tilapia Oreochromis niloticus (LINNE I779), fingerlings. Int Res J Agric Sci Soil Sci. 2011;1:142-50.

9. Vivekraj P, Vinotha S, Vijayan A, Anand G V. Preliminary phytochemical screening and GC-MS analysis of methanolic extract of Turnera subulata Smith ( Passifloraceae ). J Phytopharm. 2017;6:174-7.

10. Nandagopalan V, Gritto MJ, Doss A. GC-MS analysis of bioactive components of the methanol extract of Hibiscus tiliaceus Linn . Asian J Plant Sci Res. 2015;5:6-10. on the survival, morphology and behaviour of an Indian strain of dengue vector, Aedes aegypti L . ( Diptera: Culicidae ). J Mosq Res. 2017;5:1-9; doi:10.5376/jmr.2015.05.0007

377 12. Sharma V, Chaudhary U, Singh R, Agarwal A. Achyranthes aspera: phytochemical estimation. Am J PharmTech Res. 2013;3:242-51.

379 13. Eshete MA, Asfaw Z, Kelbessa E. A review on taxonomic and use diversity of the 380 family Amaranthaceae in Ethiopia. J Med Plants Stud. 2016;4:185-94.

381 14. Habtamu A, Mekonnen Y. Evaluation of the antibacterial activities of leaf extracts of 382 Achyranthus aspera. Afr J Bacteriol Res. 2017;9:9-14; doi:10.5897/JBR2015.0189 
383 15. Reddy CV, Kamble A. Toxicity study of Achyranthus aspera. Int Lett Nat Sci. 384 2014;14:85-96; doi: 10.18052/www.scipress.com/ILNS.14.85

385 16. Reddy RBD, Reddy PN, Prathibha N, Mounica TM, Phanikumar A, Ravindra M. 386 Pharmacognostic, preliminary phyto chemical and pharmacological studies on the roots 387 of Achyranthes aspera. IJPPR. 2012;4:139-41.

388 17. Mandefro B, Mereta ST, Ambelu A. Efficacy of Achyranthes aspera ( L .) as a 389 molluscicidal bait formulation against fresh water snail Biomphalaria pfeifferi. Evidence390 Based Complement Altern Med. 2018;2018:1-7; doi:10.1155/2018/2718585

391 18. Mandefro B, Mereta ST, Tariku Y, Ambelu A. Molluscicidal effect of Achyranthes 392 aspera L. (Amaranthaceae) aqueous extract on adult snails of Biomphalaria pfeifferi and 393 Lymnaea natalensis. Infect Dis Poverty. 2017;6; doi:10.1186/s40249-017-0349-4

394 19. Dey A. Achyranthes aspera L: phytochemical and pharmacological aspects. Int J 395 Pharm Sci Rev Res. 2011;9.

396 20. Varadharaj V, Kuppan M. Identification and determination of bioactive 397 phytochemical constituents from the hydro-alcoholic extract of Achyranthes aspera 398 whole plant by gas chromatography-mass spectrometry analysis. 2015;8:6-10.

399 21. Kumar V, Sharma A, Thukral AK, Bhardwaj R. Phytochemical profiling of 400 methanolic extracts of medicinal plants using GC-MS. Int J Res Dev Pharm L Sci. $401 \quad 2016 ; 5: 2153-8$.

402 22. Breuil C, Damien G. Fisheries in the ESA-IO Region: Profile and trends Country 403 review 2014. Ebene; 2014.

404 23. Endebu M, Lema A, Genet T, Mitike A, Regassa B, Dejen E, et al. Fisheries baseline 405 survey describing status of fisheries in Lake Zeway, Ethiopia. J Fish Livest Prod. 2015;3; 406 doi:10.4172/2332-2608.1000129

407 24. Janko AM. Economics and management sciences fish production, Consumption and 408 management in Ethiopia. Int J Econ Manag. 2014;3; doi:10.4172/2162-6359.1000183

409 25. Tesfahun A. Review in current problems of Ethiopian fishery: Incase of human and 410 natural associated impacts on water bodies. Int J Fish Aquat Stud. 2018;6:94-9. 
411 26. Kushwaha MP. Replacement of fish meal by soybean (Glycine max ) in the

412 formulation of fish feed ingredients essential for immunostimulation and growth 413 performance of carps. Int J Fauna Biol Stud. 2013;1:35-8.

414 27. Okey I, Keremah R, Ikpi G, Ebeniro L. Toxicity of leaf powder of Lepidagathis 415 alopecuroides to Nile tilapia Oreochromis niloticus juveniles. Afr J Food Sci. 416 2013;7:128-33; doi:10.5897/AJFS11.126

417 28. Syngai G, Dey S, Bharali R. Evaluation of toxicity levels of the aqueous extract of 418 Allium sativum and its effects on the behavior of juvenile common carp (Cyprinus carpio 419 1., 1758). Asian J Pharm Clin Res. 2016;9:417-21.

420 29. OECD. Guideline for Testing of Chemicals: Fish, Acute Toxicity Test (Draft revised 421 version). 2014.

422 30. EPA. Methods for measuring the acute toxicity of effluents and receiving waters to 423 freshwater and marine organisms 5th ed. EPA. 2002;84; doi:10.1590/S0001$424 \quad 37652012005000059$

425 31. EPA. Ecological effects test guidelines fish acute toxicity test, freshwater and marine. 426 1996. Washington, DC.

427 32. Ayuba VO, Ofojekwu PC, Musa SO. Acute toxicity of Clarias gariepinus exposed to 428 Datura innoxia leaf extract. J Med Plants Res. 2012;6:2453-7; 429 doi:10.5897/JMPR11.1641

430 33. Pereyra PJ, Rossini GP, Darrigran G. Toxicity of neem's oil, a potential biocide 431 against the invasive mussel Limnoperna fortunei (Dunker 1857). An Acad Bras Ciênc. 432 2012;84; doi:10.1590/S0001-37652012005000059.

433 34. Upadhyay A, Singh DK. Pharmacological effects of Sapindus mukorossi. Rev Inst 434 Med Trop Sao Paulo. 2012;54:273-80; doi:10.1590/S0036-46652012000500007

435 35. Singh P, Singh A. Acute toxic effects of medicinal plant Jatropha gossypifolia on 436 non- target fish and mice. Wudpecker J Agric Res. 2012;1:433-8.

437 36. Pereira-Filho AA, France CRC, Oliveira DS, Mendes RJA, Goncalves RJS, Rosa IG. 438 Evaluation of the molluscicidal potential of hydroalcoholic extracts of Jatropha 
441 37. Belete EM. Schistosomiasis Control Strategies, with Emphasis on Snail Control 442 Using Molluscicides. Int J Heal Sci Res. 2015;5:572-84.

443 38. Adetunji VO, Salawu OT. Efficacy of ethanolic leaf extracts of Carica papaya and 444 Terminalia catappa as molluscicides against the snail intermediate hosts of 445 schistosomiasis. J Med Plants Res. 2010;4:2348-52; doi:10.5897/JMPR10.468.

446 39. Ghimire K, Banerjee J, Gupta AK, Dahal P. Phytochemical constituents and 447 pharmacological uses of medicinal plant Achyranthes aspera: a review. World J Pharm 448 Res. 2015;4:470-89.

40. Srivastav S, Singh P, Mishra G, Jha K, Khosa R. Achyranthes aspera-An important medicinal plant: A review. J Nat Prod Plant Resour. 2011;1:1-14. Insecticidal activities of essential oils extracted from three species of Poaceae on Anopheles gambiae spp, major vector of malaria. St Cerc St CICBIA. 2010;11:411-20.

42. Aladesanmi, A J. Tetrapleura tetraptera: Molluscicidal activity and chemical constituents. Afr J Trad CAM. 2007;4:23-36.

43. Ojutiku R, Avbarefe E, Kolo R, Asuwaju F. Toxicity of Parkia biglobosa pod extract on Clarias gariepinus juveniles. Int J Fish Aquac. 2012;4:133-8; doi:10.5897/IJFA11.118

44. Orji OU, Ibiam UA, Aja PM. Acute toxicity studies of the lyophilized aqueous extract of Psychotria microphylla leaf on Clarias gariepinus juveniles. Int J Biol Biol Sci. 2014;3 June:38-44.

\section{Tables and Figures}

463 Figure 1. Phytoconstituents of A. aspera leaf ethanolic extract analysed by GC-MS.

464 (a) Cyclohexane, 1-methyi-4-(2-hydroxyethyl) $\mathrm{C}_{9} \mathrm{H}_{18} \mathrm{O}$; (b) Benzene, (1-methylpropyl) $465 \mathrm{C}_{10} \mathrm{H}_{14}$; (c) Cis-p-mentha-1(7),8-dien-2-ol $\mathrm{C}_{10} \mathrm{H}_{16} \mathrm{O}$; (d) 1,2-Benzenedicarboxilic acid, 466 butyl 8-methylnonyl ester $\mathrm{C}_{22} \mathrm{H}_{34} \mathrm{O}_{4}$; (e) Octadecanoic acid, 2-hydroxy-1,3467 propanediylester $\mathrm{C}_{39} \mathrm{H}_{76} \mathrm{O}_{5}$; (f) Oleic acid,eicosyl eter $\mathrm{C}_{38} \mathrm{H}_{74} \mathrm{O}_{2}$; (g) Benzene, 1,3-diethyl 
$468 \mathrm{C}_{10} \mathrm{H}_{14} ;$ (h) Naphthalene,2-methyl $\mathrm{C}_{11} \mathrm{H}_{10}$; (i) Naphthalene,1,7-dimethyl $\mathrm{C}_{12} \mathrm{H}_{12}$; 469 (j) Eicosanoic acid $\mathrm{C}_{20} \mathrm{H}_{40} \mathrm{O}_{2}$; (k) Benzene, 1,2,3-trimethyl $\mathrm{C}_{9} \mathrm{H}_{12}$; (l) Oleic acid $470 \quad \mathrm{C}_{18} \mathrm{H}_{34} \mathrm{O}_{2}$.

471 
Figures
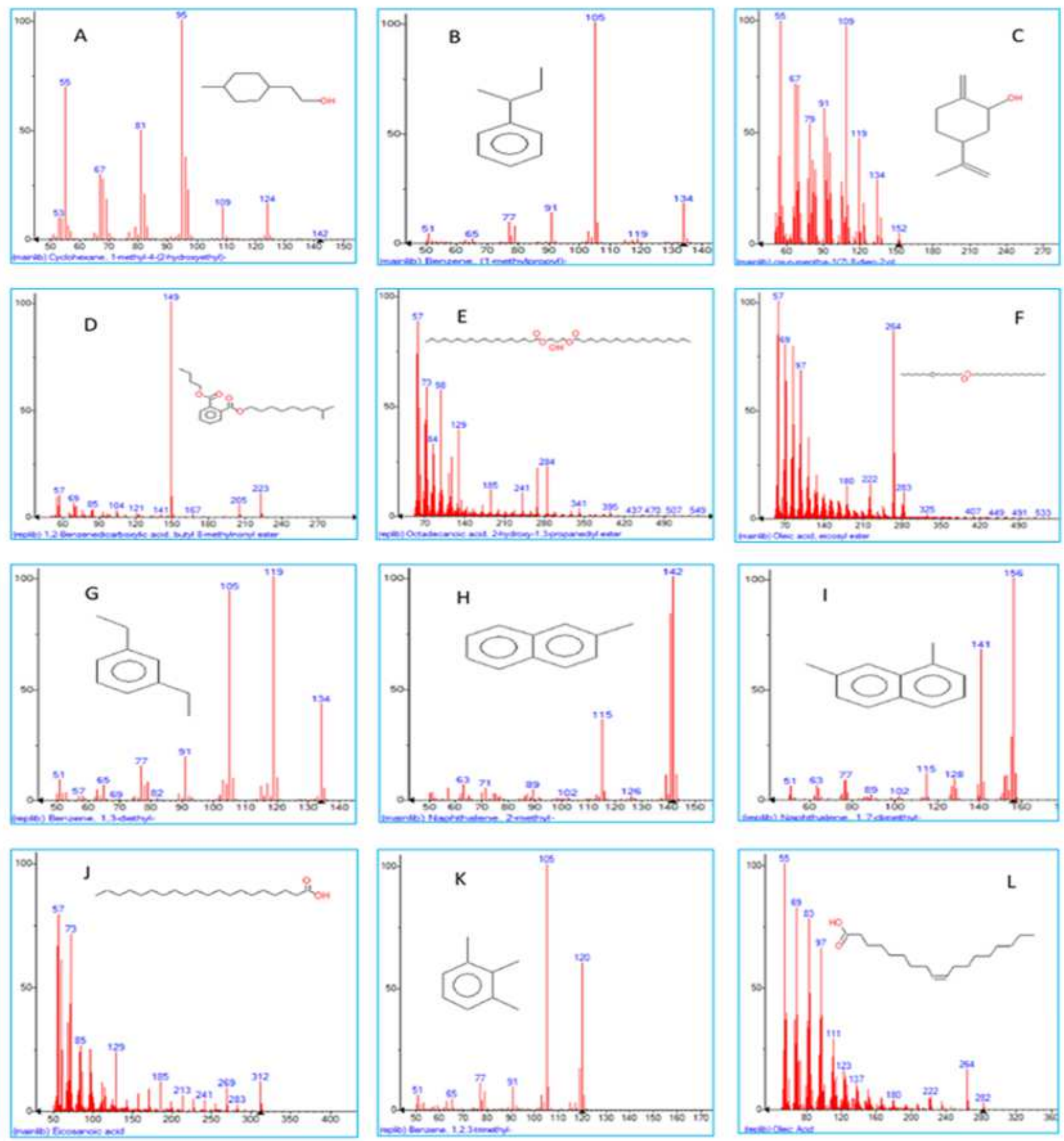

Figure 1

Phytoconstituents of A. aspera leaf ethanolic extract analysed by GC-MS. (a) Cyclohexane, 1-methyi-4-(2hydroxyethyl) $\mathrm{C} 9 \mathrm{H} 180$; (b) Benzene, (1-methylpropyl) C10H14; (c) Cis-p-mentha-1(7),8-dien-2-ol C10H160; (d) 1,2-Benzenedicarboxilic acid, butyl 8-methylnonyl ester C22H34O4; (e) Octadecanoic acid, 2-hydroxy- 
1,3-propanediylester C39H7605; (f) Oleic acid,eicosyl eter C38H74O2; (g) Benzene,1,3-diethyl C10H14; (h) Naphthalene,2-methyl C11H10; (i) Naphthalene,1,7-dimethyl C12H12; (j) Eicosanoic acid C2OH40O2; (k) Benzene, 1,2,3-trimethyl C9H12; (I) Oleic acid C18H3402. 